\title{
Study on the Beekeeping Situation, the Level of Beekeepers Knowledge Concerning Local Honeybee Subspecies, Their Productive Characteristics, and Behavior in Eastern Amhara Region, Ethiopia
}

\author{
Tessema Aynalem Abejew ${ }^{1}$ and Zeleke Mekuriaw Zeleke ${ }^{2}$ \\ ${ }^{1}$ Department of Animal Production and Technology, Bahir Dar University, College of Agriculture and Environmental Science, \\ P.O. Box 5501, Bahir Dar, Ethiopia \\ ${ }^{2}$ International Livestock Research Institute, Nairobi, Kenya \\ Correspondence should be addressed to Tessema Aynalem Abejew; tessemaaynalem@gmail.com
}

Received 4 November 2016; Revised 23 February 2017; Accepted 15 March 2017; Published 29 March 2017

Academic Editor: Innocenzo Muzzalupo

Copyright (C) 2017 Tessema Aynalem Abejew and Zeleke Mekuriaw Zeleke. This is an open access article distributed under the Creative Commons Attribution License, which permits unrestricted use, distribution, and reproduction in any medium, provided the original work is properly cited.

\begin{abstract}
The study was undertaken in Amhara National Regional State, northeastern zones of Ethiopia in 2013/2014. The objectives of the study were to identify the existing local honeybees and their productive characteristics and behavior and generate baseline information for further research and development. Out of two zones, three potential districts have been purposively selected based on their potential. A total of 260 beekeepers personal interviewees were administered using structured and semi-structured questionnaires. The study was designed to address behavioral characteristics and productivities of different local honeybees. About $98.8 \%$ of interviewees were male and about $73.9 \%$ were at stages of literacy ranging from read and write to diploma level. Nearly $73.4 \%$ of beekeepers have more than 5 years of beekeeping experience. The average honeybee colony holding was 4.6 in highlands, 2.8 in mid altitude, and 2.7 in lowlands. About 34\% of respondents harvest honey more than two times a year. Based on the honeybees individual color appearance, aggressiveness, and honey productivity, about $36.7 \%$ of the respondents have identified three local honeybee types, namely, brown red, black, and mixed. Brown red colored honeybee ecotype has been selected as best due to their better honey production, low aggressiveness, and relatively high reproductive swarming tendency.
\end{abstract}

\section{Introduction}

Beekeeping is long standing and deep rooted household activity for rural communities of Ethiopia where millions of honeybee colonies are kept in traditional hives in backyard and in forest using different management practices at different geographical locations $[1,2]$. Ethiopia is country with different agroecologies, which sustain various vegetation, and agricultural crops, which produce nectar and pollen for honeybees [3]. The overall honeybee colonies present in Ethiopia are estimated to be over 10 million [4]. Amhara Regional State is endowed with varied agroecological zones that are suitable for beekeeping and sustains different local honeybees. About 1.03 million honeybee colonies are estimated to be found in the region [5], which is a real reflection of the potentiality of the region. Beekeepers have also better knowledge to identify honeybee ecotypes and manage their honeybee colonies. In the eastern part of the region, large areas of inaccessible lands for crop cultivation and livestock grazing (along escarpments, hills, and undulating mountains) are covered with various types of bushes, which are potential for beekeeping [6]. Hence, the study would contribute much in generating appropriate information on honeybee ecotypes found and their behavior in the eastern parts of Amhara Region, Ethiopia.

Honeybees, like all other living things, vary among themselves in traits such as temperament, disease resistance, and productivity. The environment has a large effect on differences among honeybee colonies, but the genetic makeup 
TABLE 1: Age of the household head (years) by districts.

\begin{tabular}{|c|c|c|c|c|c|}
\hline Districts & Number of cases & Mean age & Minimum & Maximum & Standard deviation \\
\hline Dawwa Cheffa & 57 & 42.63 & 20 & 70 & 13.56 \\
\hline Gubalafto & 120 & 45.2 & 25 & 75 & 10.9 \\
\hline Sayint & 81 & 45.83 & 25 & 77 & 10.64 \\
\hline All districts & 258 & 44.55 & 23.3 & 74 & 11.7 \\
\hline
\end{tabular}

of a colony can also impact the characteristics that define a particular group. Beekeepers have knowledge about different genetic stocks that have distinctive characteristics, so they have utilized different strains to suit their particular purpose: whether it is honeybee pollination, a honey crop, or bee production [7]. Though the color, size, and distribution of some races in the country are documented, their performance was not well studied so far. Therefore, performance evaluation of this honeybee race in its natural agroecological distribution is very crucial to assess the potentiality of the races (local honeybees) and to lay foundation for future selection and improvement of the local honeybees. This research study was undertaken to identify local honeybees and their behavior based on beekeepers indigenous knowledge in Eastern Amhara Region of Ethiopia for further on-station and onfarm evaluation and intensification of beekeeping.

The Specific objectives of the study were as follows:

(i) To identify the existing local honeybees in Eastern Amhara Region

(ii) To characterize behavior and productiveness of those local honeybees

\section{Materials and Methods}

2.1. Description of the Study Area. The study was conducted in Eastern Amhara National Regional State taking three potential districts (Sayint, Gubalafto, and Dewa Chefa). Beekeeping is a common practice in the study districts. Beehives are virtually kept at backyards and they are widely practiced across all the kebeles of the districts. There are three types of hives in use (traditional, transitional, and Dadant hives) in the study area.

These districts have represented three major agroecological zones of highland, mid altitude, and lowland, respectively. There are cold submoist agroecology of 1800-2200 meters above sea level, moderate or tepid submoist agroecology having an altitude of 1500-1800 meters above sea level, and hot to warm submoist agroecology having an altitude of $<1500$ meters above sea level, respectively [8].

2.2. Sampling Procedure and Data Collection. During the study, both primary and secondary data sources were used and qualitative and quantitative data were generated using conventional survey method using structured and semistructured questionnaire. Out of two zones, three potential districts, $20 \%$ from Gubalafto, $15 \%$ from Sayint, and $10 \%$ interviewees from Dewa Chefa, have been purposively selected based on their potential. The interviewee household selection was carried out from list of beekeeper farmers registered as members in each district. A total of 260 beekeepers personal interviews were administered based on structured and semi-structured questionnaires that were first developed in English and then translated into local language. The study was designed to address identifying local honeybees and their behavioral characteristics and productivities in North Eastern Ethiopia.

2.3. Statistical Analysis. The data were analyzed using Statistical Package for Social Science, SPSS version 20 software (SPSS, 2012) to carry out descriptive statistics on qualitative and quantitative variables of local honeybees and productiveness.

\section{Result and Discussion}

3.1. Household Characteristics. About $98.8 \%$ of respondents were male. The traditional idea underscores beekeeping to be men's job due to physical reasons. Actually this belief might not hold true if females are given equal chance in heading the family as that of their male counterparts. Majority of the respondents (about 98.3\%) are married while the remaining is single, divorced, and lonely due to death of wife, respectively. The mean age and standard deviation of beekeepers are given in Table 1. Age and experience have great implication on identifying local honeybees and their production and behaviors.

3.1.1. Education Level of Respondents. Regarding the educational status of the respondents about $26.1 \%$ did not receive any education while about $73.9 \%$ are at stages of literacy ranging from read and write to diploma level. This result is in line with result noted by $[9,10]$ that have found more than $62 \%$ of the sample respondents in the region to be at the stage of literacy ranging from read and write to diploma.

The education level reflects persuasion of beekeepers and proper management of their honeybee colonies and they characterize local honeybees based on different behaviors and honey productivities. The average yield of honey (in $\mathrm{kg}$ ) harvested from different types of hives by districts has been given in Table 2.

3.1.2. Beekeeping and Experience. From the result obtained, about $26.6 \%$ of beekeepers have less than 5 years, $19.2 \%$ have 6 to 10 years, $24.1 \%$ of them have $11-15$ years, $12.5 \%$ have 16-20 years, and $17.5 \%$ have above 21 years of beekeeping experience. In other words, about $83.4 \%$ of beekeepers have more than five years of beekeeping experience. The average beekeeping experience was 12.9 with standard deviation of 9.02 and range of 3 to 40 years. The beekeeping experience has positive correlation with usage of improved beekeeping technologies $(p<0.01)$. This is similar with [11]. This helps 
TABLE 2: Average yield of honey (kg) harvested from different types of hives by districts.

\begin{tabular}{|c|c|c|c|c|c|c|c|c|c|c|c|c|}
\hline \multirow{2}{*}{ District } & \multicolumn{4}{|c|}{ Traditional hive } & \multicolumn{4}{|c|}{ Top bar hive } & \multicolumn{4}{|c|}{ Frame hive } \\
\hline & $N$ & Mean & $\mathrm{SD}$ & $\operatorname{Max}$ & $N$ & Mean & $\mathrm{SD}$ & $\operatorname{Max}$ & $N$ & Mean & $\mathrm{SD}$ & Max \\
\hline Sayint & 78 & 10.33 & 7.66 & 35 & 11 & 16.73 & 11.57 & 35 & 3 & 35.33 & 4.50 & 40 \\
\hline Gubalafto & 120 & 10.30 & 5.6 & 30 & 120 & 16 & 7.26 & 32 & 120 & 13.1 & 6.93 & 40 \\
\hline D/Cheffa & 49 & 8.35 & 6.48 & 35 & 4 & 2.75 & 1.26 & 4 & 22 & 11.14 & 8.12 & 30 \\
\hline All districts & 247 & 9.66 & 6.58 & 35 & 135 & 11.83 & 6.7 & 35 & 145 & 19.86 & 6.52 & 40 \\
\hline
\end{tabular}

beekeepers to have indigenous knowledge to identify local honeybees and their behavior and productivities.

3.1.3. Honeybee Colony Holding. In general, the beekeeping business was practiced at a very small-scale level in the study areas. Considering the whole sample from all locations, most farmers (about $48.4 \%$ ) owned two or less, $15 \%$ owned 3 to 4 , and only $6.6 \%$ owned 5 or more honeybee colonies in traditional hives with the maximum occupation of 10 honeybee colonies. The average total honeybee colony holding was 4.6 in highlands, $2.8 \mathrm{in} \mathrm{mid} \mathrm{altitude,} \mathrm{and} 2.7$ in lowlands. The total honeybee colony holding has positive correlation $(p<0.01)$ with altitude.

3.1.4. Honey Harvesting and Yield. In the study area, about $66 \%$ of the sample beekeepers harvest honey only once, $20 \%$ twice, and about $14 \%$ three times in a year depending on the location of their apiaries: near irrigation areas, near forest, and water source areas. However, harvesting technique is still very traditional. About $41.3 \%$ of the interviewed Zander hive user households collect comb honey from frame hives by distracting honeycomb and $20 \%$ use no protective materials to do well on frame hives. This underestimates the productivity of local honeybees. As exit strategy, the districts have tried to share essential beekeeping equipment centrally owned by district office. However, having knowledge of the correct time for honey harvesting is important in order to provide proper and timely extension service as well as technical support for beekeepers who share beekeeping equipment and accessories.

The main harvesting periods of the three agroecological zones of Eastern Amhara Region were October to November, where October is a peak harvesting month to obtain the largest quantity and quality of honey. The harvesting periods correlate with availability of moisture and peak flowering period for many honey plants including pulse and oil crops. In highland and mid altitude agroecological zones, honey harvesting starts in October and ends in December. In lowland areas, honey harvesting starts in September and ends in the beginning of December, while October is a peak harvesting period as shown in Figure 1.

3.2. Local Honeybees and Their Behavior. About $36.7 \%$ of the respondents know that there are three local honeybees based on physical appearance of color, namely, brown red colored, black, and mixed honeybee colony, which is the mixture of brown red colored and black geographical local honeybees. Others (about 63.3\%) only know the two races: brown red colored and black. This is similar to [12]; the

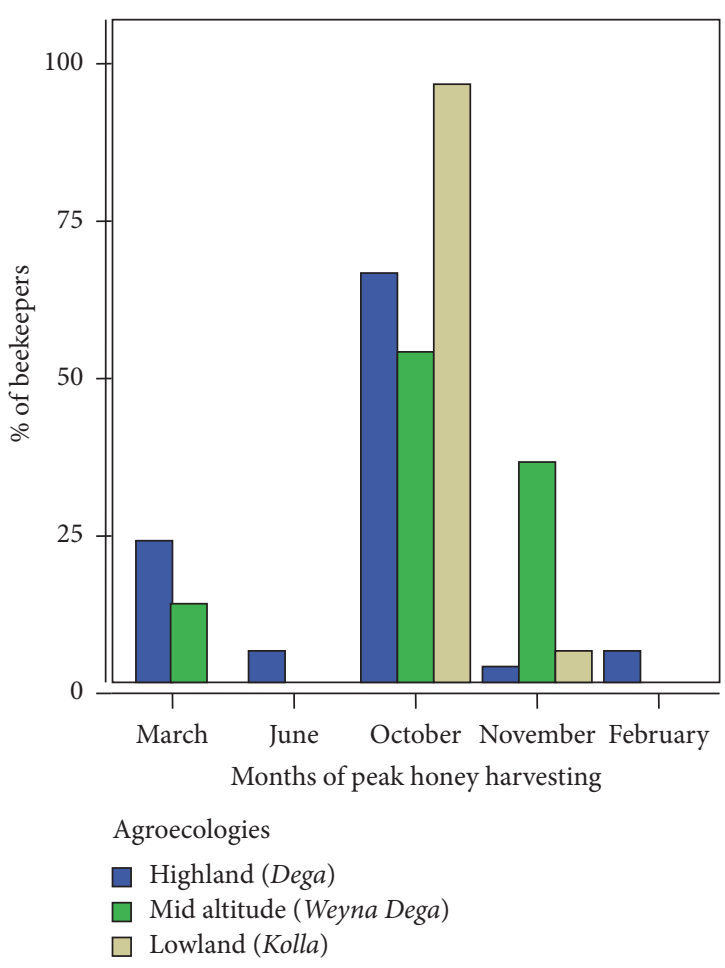

FIgURE 1: The peak honey harvesting periods in agroecological zones.

honeybees at higher altitudes differ from lower surrounding populations in both size and pigmentation. As a country, five geographical races of honeybees (Apis mellifera monticola, Apis mellifera bandasii, Apis mellifera scutellata, Apis mellifera jemenitica, and Apis mellifera woyi-gambella) are reported to exist in different agroecological zones [4]. As far as their characteristic is concerned, it has been given in Table 3 .

Apis mellifera defensive behavior is a complex trait that involves individual worker behavior and a coordinated colony response with a group effect. As stated by [13], genetic control of defensive behavior in honeybees and this parameter have been included in many genetic breeding programs. The African honeybees are highly defensive and much more aggressive towards humans and animals. They respond more rapidly and intensely than European bees and usually sting in larger numbers [14-17]. They also tend to have more aggressive behavior than their European or American counterparts, a trait which also makes them more productive and resilient at their native range. This aggression 
TABLE 3: Different characteristic behaviors of local honeybees.

\begin{tabular}{|c|c|c|c|c|c|}
\hline Local honeybees & Rank & Aggressiveness & Productivity & Reproductive swarming tendency & Absconding tendency \\
\hline \multirow{4}{*}{ Brown red } & Low & 50.8 & 11.7 & 2.5 & 17.5 \\
\hline & Medium & 32.5 & 20.8 & 20.8 & 11.7 \\
\hline & High & 15 & 62.5 & 38.3 & 14.2 \\
\hline & No comparison idea & 1.7 & 5 & 38.3 & 56.7 \\
\hline \multirow{4}{*}{ Mixed } & Low & 2.5 & 2.5 & 1.7 & 3.4 \\
\hline & Medium & 28.6 & 21.0 & 16.0 & 15.1 \\
\hline & High & 5.9 & 10.9 & 4.2 & 3.4 \\
\hline & No comparison idea & 2.5 & 5.0 & 17.6 & 17.6 \\
\hline \multirow{4}{*}{ Black } & Low & 3.3 & 15.0 & 10.0 & 5.8 \\
\hline & Medium & 16.7 & 53.3 & 26.7 & 15.0 \\
\hline & High & 78.3 & 25.0 & 25.0 & 22.5 \\
\hline & No comparison idea & 1.7 & 6.7 & 37.5 & 56.7 \\
\hline
\end{tabular}

TABLE 4: Local honeybees preferred to hive in improved hives.

\begin{tabular}{lcccc}
\hline Agroecology & \multicolumn{4}{c}{$\begin{array}{c}\text { Local honeybees preferred to hive in } \\
\text { improved hives }\end{array}$} \\
& Brown red & Mixed & Black & $\begin{array}{c}\text { No } \\
\text { preference }\end{array}$ \\
\hline Highlands & $70 \%$ & 0 & $7.5 \%$ & $22.5 \%$ \\
Mid altitude & $85 \%$ & 0 & 12.5 & $2.5 \%$ \\
Lowland & $20 \%$ & $17.5 \%$ & $35 \%$ & $27.5 \%$ \\
\hline Average & $58.3 \%$ & $5.8 \%$ & $18.3 \%$ & $17.5 \%$ \\
\hline
\end{tabular}

trait can be manipulated and utilized for the continent's advantage [18] through selective breeding. Although the African honeybee is very aggressive, some tend to sting less than others and are more docile. Aggressive strains respond faster in greater numbers although each bee stings once [1416]. The aggression trait can be manipulated and utilized for the continent's advantage [18] through selective breeding. Generally, the aggressive behavior of honeybees is associated with environmental factors, genetics, strength of colonies, large stores, and amount of alarm produced [19]. It is possible to select less defensive honeybees based on their reaction.

African honey bees frequently swarm to establish new nests [20-22]. The causes of swarming may be many but African honeybees strains are known to swarm heavily and abscond in greater frequencies than their European counterparts. African honeybee colonies abscond readily and build comb with the smaller-sized cells [23, 24]. Absconding is abandoning of a nest by a colony which forms a swarm and presumably reestablishes itself elsewhere [25]. Shortage of resources and other factors could cause the absconding behavior of African honeybees [26]

Beekeepers preferred different geographical local honeybees to hive in improved hives across agroecologies (Table 4). Morphometric variance among colonies of a natural honeybee population can be attributed to two proximate causes. Because queen honeybees are polyandrous $[27,28]$, honeybee colonies may consist of several too many patrilines. Some characteristics are little influenced by the environment but highly correlated with honey production and can assist in selecting colonies with greater production capacity for more efficient analysis [29]. African honeybee traits such as resistance to diseases and pests, survival to harsh tropical conditions, foraging, and defensive behaviors are of agricultural value and they influence pollination and hive productivity either directly or indirectly [30-33]. For the African farmers to realize economic benefits through hive productivity and pollination, apiculture should be improved through proper management and use of specialized bee for production [34] perhaps through selective breeding to augment the traditional apicultural practices. Generally, brown red colored honeybee ecotype has been selected first due to its better honey productivity, low aggressiveness, and relatively high reproductive swarming tendency. Based on the result, evaluation of different strains of honeybees at their original ecology is important to use their potential and to lay foundation for future selection and improvement of local honeybee races.

Even though less preferred, the reasons for preference of brown red colored local honeybees in lowland are their good honey productivity and low stinging behavior on beekeepers as well as their families during inspection and low damage on animals on accidental contact or after inspection and high reproductive swarming. Since the price of honeybee colonies is high and the reproductive swarming frequency is low in the study area, fast-reproducing colonies are wanted, whereas the reasons for preferring black local honeybees are their high drought or feed shortage tolerance. Still some beekeepers believe that all local honeybees have their own strong and weak behaviors; however, improving management can increase either of colonies' productivity.

The same reasons have been given for preference of brown red colored and black local honeybee colonies in mid altitude as highlands but the black local honeybees are more defensive than brown red colored and frequently give reproductive swarm. Moreover, black local honeybees construct good quality white colored comb honey, which is attractive in market. The color may be determined by availability of good flowers. They also highly defend their hives against other intruder animals without the help of beekeeper. 


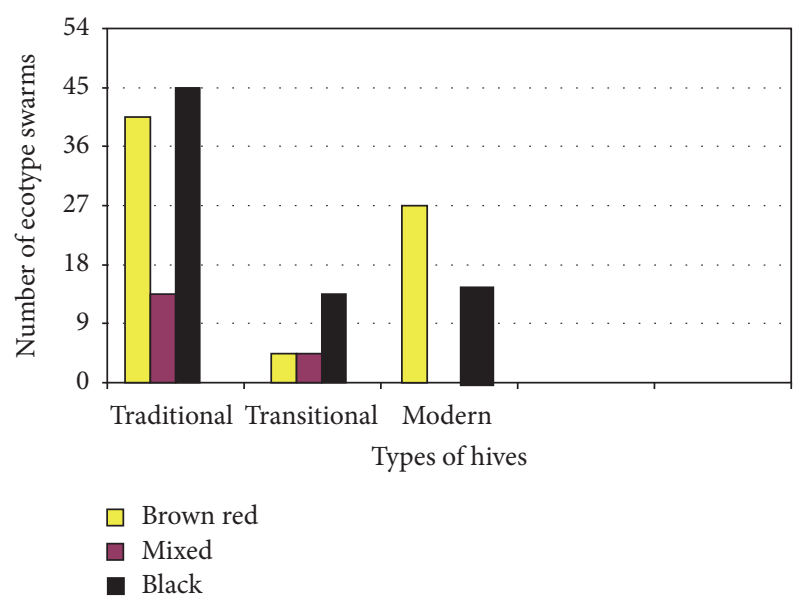

FIgURE 2: Number and types of local honeybee colonies swarmed from different hives during study.

According to the beekeepers response, suitable honeybee ecotype is usually defined in terms of its ability of gathering large amount of stores and its potential for management and manipulation. Gentleness and quietness on the combs have been a major concern of beekeepers. This is in line with $[19,35]$; there exists great variation in the honeybees, which lies high potential for selecting the genetic stock easier to manage and maintain inherent advantages. Similarly, the honeybee colonies productivity and behavioral characteristics are highly affected by physical environment (altitude, vegetation, and climate). The honeybee colonies found in highland agroecological zones were dark in color, larger, and docile adapted to the natural and cultivated crops flowering year round and have fewer enemies, whereas the honeybee colonies in lowland agroecological zones (lowland hot climate zones) are generally yellowish in color, smaller in size, active, productive, and aggressive, adapted to areas with flowering plants of short flowering period, which needs fast and concentrated honeybee colony management activities. The mid altitude local honeybees are either the first swarms caught from early reproductive swarms of lowland or second migratory swarms from highland during dearth periods [36].

3.3. Reproductive Swarming. According to beekeepers response, reproductive swarming tendency of the colonies has decreased in the study area due to different reasons. Only about $20.8 \%$ of the respondents have reproductive swarms during the study. The number of local honeybees swarmed from different hives is given in Figure 2 and the months of the year where colonies swarm more were given in Figure 3. Reproductive swarming is the natural instinctive behavior of honeybees to reproduce; however, in a man-made environment swarming is often a symptom of problems within the hives [37]. Thus, successful swarm management is essential for increased honey production. While the reproductive behavior is not fully understood, several recognizable factors contribute to swarming. Of primary importance is congestion in the brood area, which is related to population size and availability of space in the

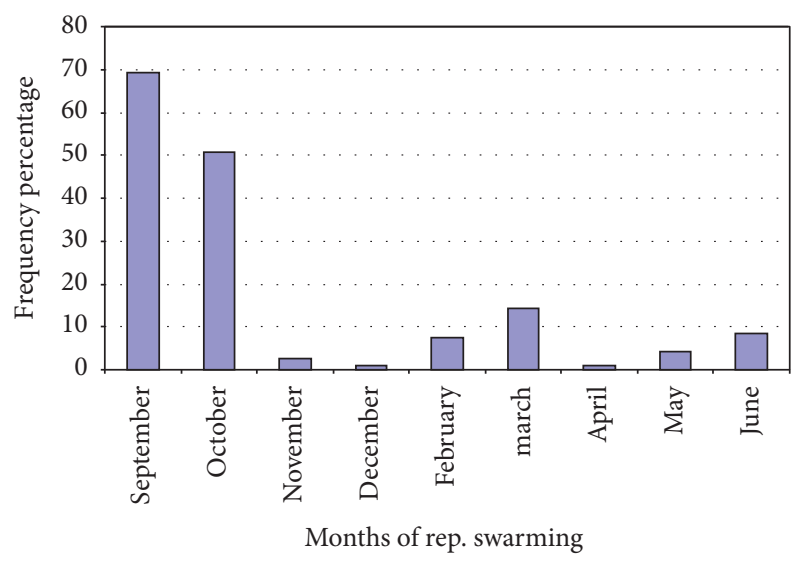

Reproductive swarming

FIGURE 3: The reproductive swarming months of the year.

hive [38]. The tendency to reproductive swarming defers with different races of honeybees and further within different breeding lines within races [39].

\section{Conclusion and Recommendations}

Beekeeping experience and indigenous knowledge of beekeepers are an input to identify different local honeybees, production potential, and biological behaviors at different localities of the country.

(i) The beekeepers have to feed their colony timely at dearth period to coincide the colony strength with flowering period to see the real productive potential of honeybee ecotype.

(ii) Morphometric analysis should be used for further research and improvement.

(iii) The behavior and productivity of selected local honeybees from each agroecologies should be tested in controlled research stations.

(iv) On-station evaluation, selection, and multiplication of selected local honeybees are the most critical issue that needs to be addressed to influence boosted honey production.

\section{Conflicts of Interest}

The authors declare that they have no conflicts of interest.

\section{References}

[1] K. Ayalew and T. Gezahegn, Suitability Classification in Agricultural Development, Ministry of Agriculture, Addis Ababa, Ethiopia, 1991.

[2] D. Girma, "Non-Wood Forest Production in Ethiopia," Addis Ababa, Ethiopia, 1998, http://www.fao.org/docrep/003/X6690E/ X6690E01.htm.

[3] A. Kassaye, Beekeeping extension activities in Ethiopia. Addis Ababa, Ethiopia, 1983. 
[4] Nuru Adgaba 2002 Geographical races of the Honeybees (Apis mellifera L.) of the Northern Regions of Ethiopia [Ph.D. dissertation], Rhodes University, Grahamstown, South Africa, 2002.

[5] CSA (Central Statistical Authority), Agricultural Sample Survey 2012/13 [2013] Report on Livestock and Livestock Characteristics, vol. II, CSA, Addis Ababa, Ethiopia, 2013.

[6] BoA. (Bureau of Agriculture), Amhara National Regional State (ANRS) Bureau of Agriculture, Strategic Plan Document, BOA, Bahir Dar, Ethiopia, 2003.

[7] M. D. Meixner, M. A. Pinto, M. Bouga, P. Kryger, E. Ivanova, and S. Fuchs, "Standard methods for characterising subspecies and ecotypes of Apis mellifera," Journal of Apicultural Research, vol. 52, no. 4, pp. 1-28, 2013.

[8] MoA, "MoA, National Livestock Development Project (NLDP)," Working Paper 1-4, MoA, Addis Ababa. Ethiopia, 1998.

[9] A. Kebede, K. Ejigu, T. Aynalem, and A. Jenberie, Assessment of the Status of Beekeeping in Amhara Region, Amhara Regional Research institute, Bahirdar, Etiopia, 2008.

[10] P. Workneh Abebe and R. Karippai, "Adapting improved box hive in Atsbi wemberta District of Eastern Zone, Tigray Region: determinants and financial benefits," IPMs (Improving Productivity and Market Access) of Ethiopian Farmers Project Working Paper 10, ILRI (International Livestock Research Institution), Nairobi, Kenya, 2008.

[11] N. Adgaba, Atlas of Pollen Grains of Major Honeybee Flora of Ethiopia, Holetta Bee Research Centre, Holetta, Ethiopia, 2007.

[12] F. Ruttner, Biogeography and Taxonomy of Honeybees, Springer, Berlin, Germany, 1988.

[13] E. Guzmán-Novoa and R. E. Page, "Genetic dominance and worker interactions affect honeybee colony defense," Behavioral Ecology, vol. 5, no. 1, pp. 91-97, 1994.

[14] D. J. C. Fletcher, "The African bee, Apis mellifera adansonii, in Africa," Annual Review of Entomology, vol. 23, no. 1, pp. 151-171, 1978.

[15] G. J. Hunt, E. Guzmán-Novoa, M. K. Fondrk, and R. E. Page Jr., "Quantitative trait loci for honey bee stinging behavior and body size," Genetics, vol. 148, no. 3, pp. 1203-1213, 1998.

[16] H. R. Hepburn and S. E. Radloff, Honeybees of Africa, Springer, Berlin, Germany, 1998.

[17] S. S. Schneider, G. DeGrandi-Hoffman, and D. R. Smith, "The African honey bee: factors contributing to a successful biological invasion," Annual Review of Entomology, vol. 49, pp. 351-376, 2004.

[18] S. K. Raina, E. N. Kioko, I. Gordon, and C. Nyandiga, "Improving forest conservation and community livelihoods through income generation from commercial insects in three Kenyan Forests," Commercial Insects and Forest Conservation, 2009.

[19] M. T. Chandler, "The African honeybees-Apis mellifera adansonii: the biological basis of its management," in Proceedings of the 1st International Conference on Apiculture in Tropical Climate, pp. 61-68, London, UK, 1976.

[20] M. Spivak, D. J. C. Fletcher, and M. D. Breed, The African Honey Bee. Westview Studies in Insect Biology, Westview Press, Boulder, Colo, USA, 1991.

[21] D. R. Tarpy, J. R. Caren, D. A. Delaney et al., "Mating frequencies of Africanized honey bees in the south western USA," Journal of Apicultural Research, vol. 49, no. 4, pp. 302-310, 2010.

[22] R. Villanueva-G and D. W. Roubik, "Why are African honey bees and not European bees invasive? Pollen diet diversity in community experiments," Apidologie, vol. 35, no. 5, pp. 481-491, 2004.
[23] T. Carrol, A Beginner's Guide to Beekeeping in Kenya, Legacy Book Press, Nairobi, Kenya, 2006.

[24] L. C. McNally and S. S. Schneider, "Seasonal cycles of growth, development and movement of the African honey bee, Apis mellifera scutellata, in Africa," Insectes Sociaux, vol. 39, no. 2, pp. 167-179, 1992.

[25] M. L. Winston, The Biology of Honey Bee, Harvard University Press, London, UK, 1987.

[26] S. S. Schneider, "Nest characteristics and recruitment behavior of absconding colonies of the African honey bee, Apis mellifera scutellata, in Africa," Journal of Insect Behavior, vol. 3, no. 2, pp. 225-240, 1990.

[27] J. Adams, E. D. Rothman, W. E. Kerr, and Z. L. Paulino, "Estimation of the number of sex alleles and queen matings from diploid male frequencies in a population of Apis mellifera," Genetics, vol. 86, no. 3, pp. 583-596, 1977.

[28] P. Neumann, R. F. A. Moritz, and J. Van Praagh, "Queen mating frequency in different types of honey bee mating apiaries," Journal of Apicultural Research, vol. 38, no. 1-2, pp. 11-18, 1999.

[29] Y. Kahya, H. V. Gençer, and J. Woyke, "Weight at emergence of honey bee (Apis mellifera caucasica) queens and its effect on live weights at the pre and post mating periods," Journal of Apicultural Research, vol. 47, no. 2, pp. 118-125, 2008.

[30] P. R. Oxley, M. Spivak, and B. P. Oldroyd, "Six quantitative trait loci influence task thresholds for hygienic behaviour in honeybees (Apis mellifera)," Molecular Ecology, vol. 19, no. 7, pp. 1452-1461, 2010.

[31] J. Paleolog, "Behavioural characteristics of honey bee (Apis mellifera) colonies containing mix of workers of divergent behavioural traits," Animal Science Papers and Reports, vol. 27, no. 3, pp. 237-248, 2009.

[32] S. D. Shruthi, Y. L. Ramachandra, and P. S. Sujan Ganapathy, "Studies on behavioural traits of two different strains of Indian honey bee Apis cerana Indica F.," World Applied Sciences Journal, vol. 7, no. 6, pp. 797-801, 2009.

[33] M. K. Wray, H. R. Mattila, and T. D. Seeley, "Collective personalities in honeybee colonies are linked to colony fitness," Animal Behaviour, vol. 81, no. 3, pp. 559-568, 2011.

[34] CBI, The EU Market in Honey and Beeswax, CBI, Amsterdam, The Netherlands, 2006.

[35] M. T. Chandler, "Apis mellifera adansoni; the biological basis of its management," in Proceedings of the 1st International Conference on Apiculture in Tropical Climates, pp. 61-66, London, UK, 1976.

[36] G. Mammo, "Practical aspects of beekeeping management in Ethiopia," in Proceedings of the 1st International Conference on Apiculture in Tropical Climates, London, UK, 1976.

[37] C. P. Dadant, First Lesson in Beekeeping, Charles Scripler's Sons, New York, NY, USA, 1980.

[38] C. H. Collison, M. Frazier, D. M. Caron et al., Beekeeping Basics: MAAREC: Delaware, Maryland, New Jersey, Pennsylvania, West Virginia, and the USDA Cooperating, 2009.

[39] F. Rutter, "African races of honeybees," in Proceedings of the 25th International Beekeeping Congress, pp. 325-344, Grenoble, France, 1975. 


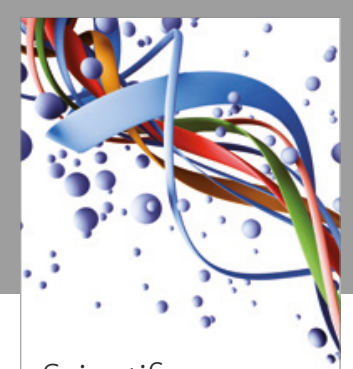

Scientifica
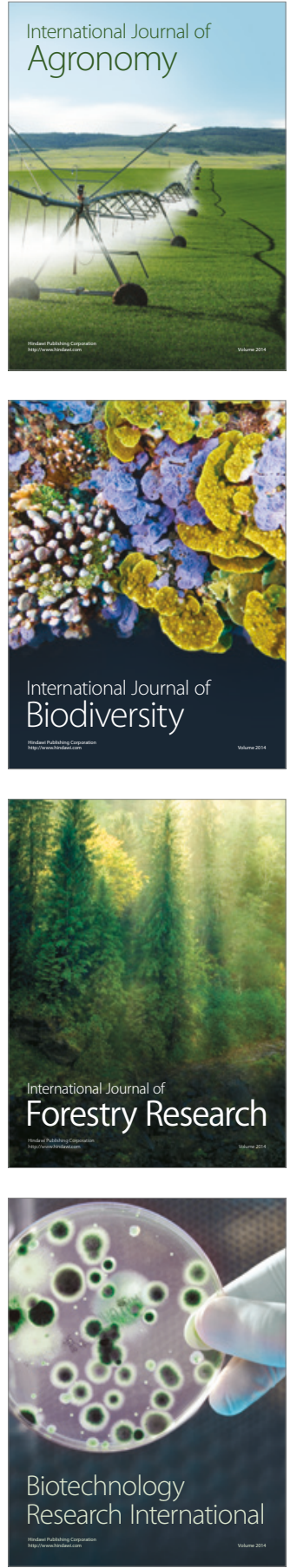
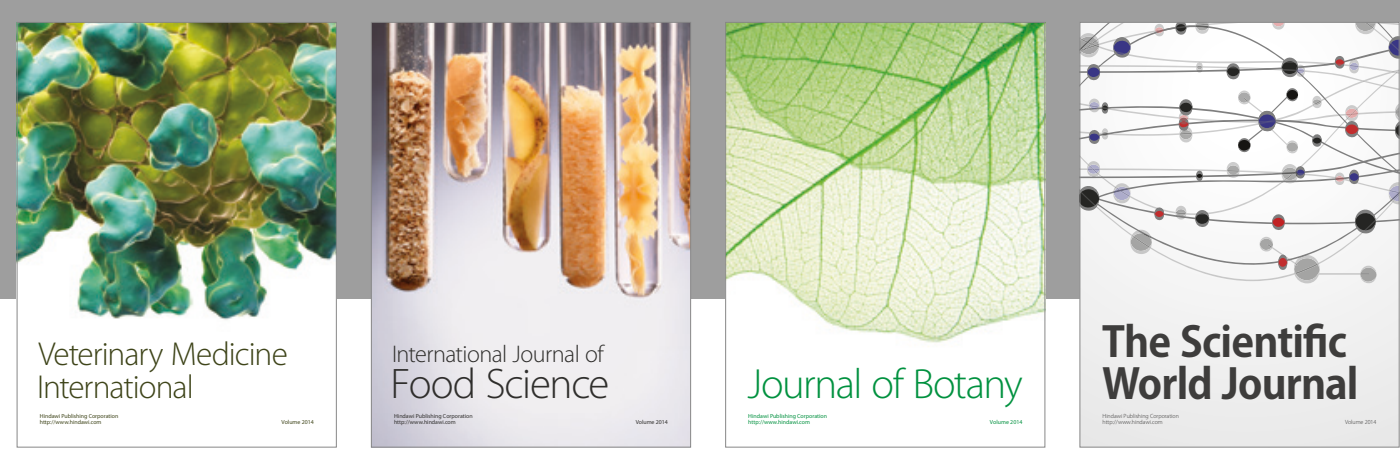

The Scientific

\section{World Journal}

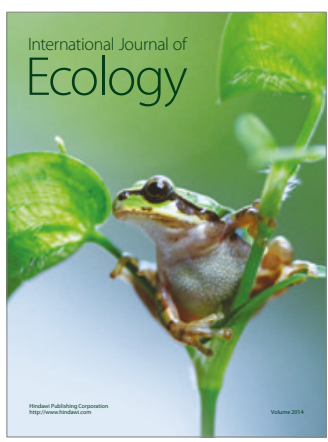

\section{Hindawi}

Submit your manuscripts at

https://www.hindawi.com
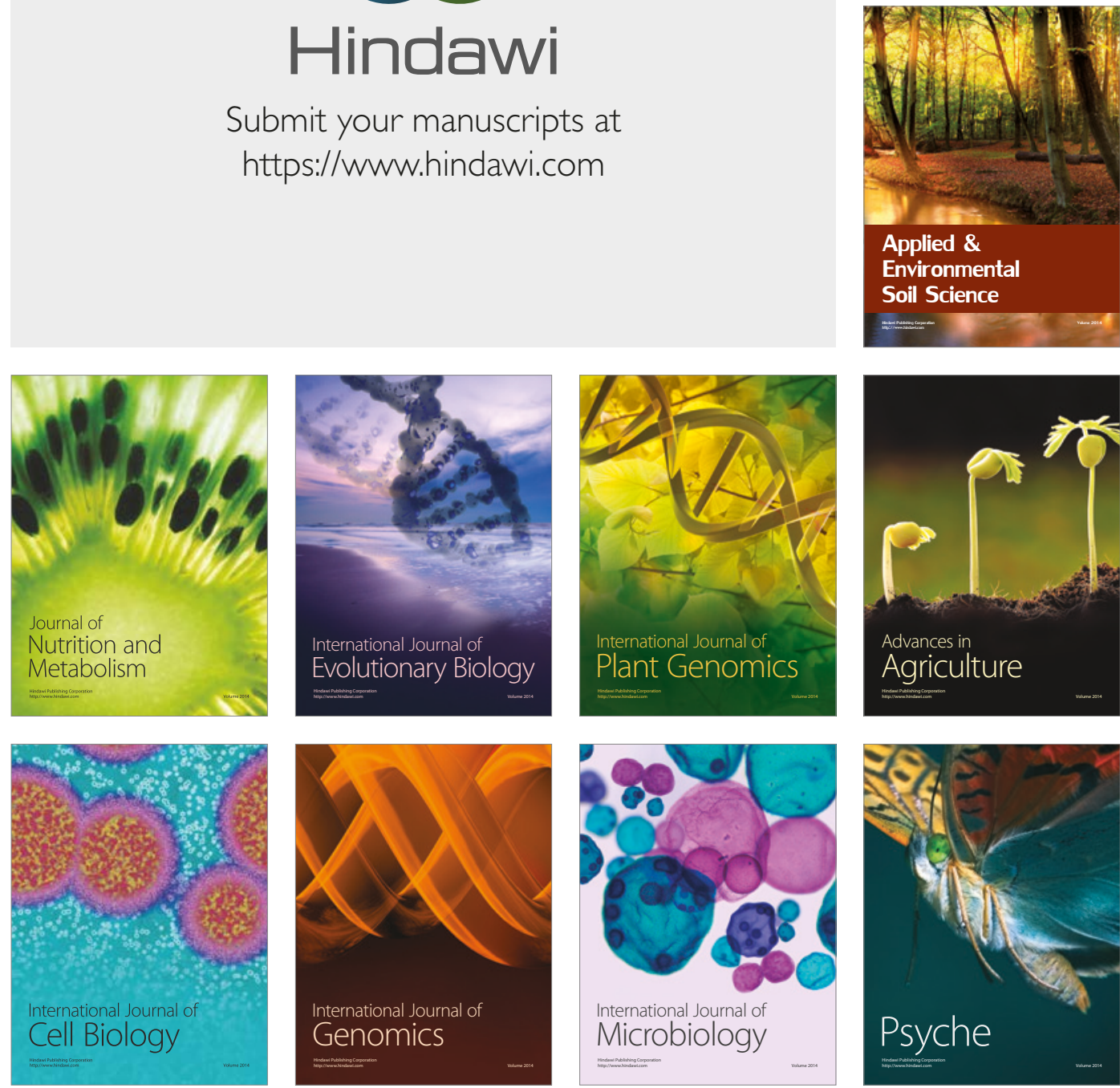

hternational Journal of Microbiology
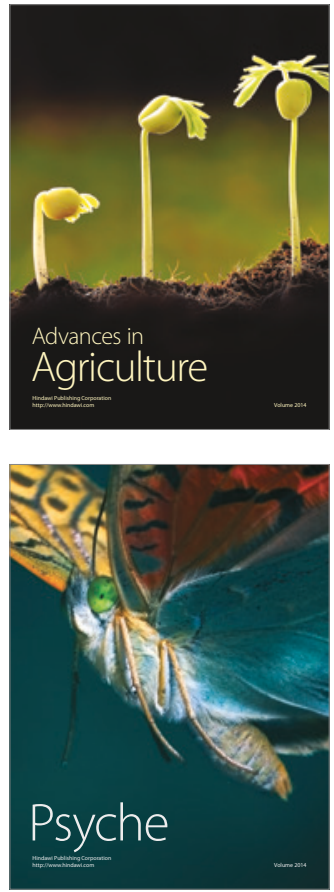